\title{
Cytomegalovirus and human herpesviruses 6 and 7: Diseases and diagnosis in transplantation
}

\author{
PAUL D GRIFFITHS, BSC, MBBS, MD, MRCPATH
}

PD GRIFriths. Cytomegalovirus and human herpesviruses 6 and 7: Diseases and diagnosis in transplantation. Can J Infect Dis 1993;4(Suppl C):26C-32C. Similarities and differences in the epidemiology of cytomegalovirus (CMV), human herpesvirus 6 (HHV-6) and human herpesvirus 7 (HHV-7) infections are reviewed. Several distinct laboratory methods have been described for each virus. For CMV in immunocompromised patients, infection is best diagnosed by identifying active infection using routine surveillance cultures. Patients with active infection can then be entered into trials of suppressive therapy (where virus excretion is from the urine or saliva) or pre-emptive therapy (where excretion is detected systemically). For HHV-6 and HHV-7, only anecdotal cases of associations with disease in immunocompromised patients have been reported. Recommendations cannot therefore be made about appropriate diagnostic strategies or about treatment since it is not clear if these viruses are pathogens or passengers.

Key Words: Diagnosis, Herpesvirus, Prognosis, Treatment

\section{Cytomégalovirus et herpèsvirus humains 6 et 7: maladies et diagnostic dans les cas de transplantation}

RÉSUMÉ: Les ressemblances et les différences épidémiologiques des infections à cytomégalovirus (CMV) à herpèsvirus humain 6 (HHV-6) et à herpèsvirus humain 7 (HHV-7) sont passées en revue. Différentes méthodes de laboratoire ont été décrites pour chacun des virus. Pour le CMV chez les patients immunocompromis, l'infection est la mieux diagnostiquée par l'identification des réactions actives à l'aide de cultures de contrôle de routine. Les patients atteints d'une infection active peuvent ensuite être inscrits à des essais pour traitement suppresseur (quand l'excrètion virale se manifeste dans l'urine ou la salive) ou traitement préventif (quand l'excrétion systémique est décelée). Pour le HHV-6 et le HHV-7, seuls des cas anecdotiques d'associations pathologiques chez des patients immunocompromis ont été déclarés. Les recommandations doivent done être formulées au sujet de stratégies diagnostiques appropriées ou au sujet de thẻrapeutiques, puisqu'on n’a pas déterminé si ces virus sont des pathogènes ou des passagers. 
$\mathrm{H}$ ERPESVIRUSES ARE CLASSICAL OPPORTUNISTS IN THAT they reactivate when a patient is otherwise debilitated. It follows that herpesviruses can regularly be found in a variety of medical conditions which are immunocompromising or which require immunosuppressive drugs for their treatment. However, the mere presence of a herpesvirus in a patient does not necessarily mean that disease will result, and criteria which should be satisfied before a herpesvirus is associated with a particular disease have been reviewed. This paper summarizes how and why infections with two herpesviruses should be sought in transplant patients.

\section{CYTOMEGALOVIRUS}

As reviewed elsewhere in this issue, it is clear that cytomegalovirus (CMV) is the cause of several distinct clinical syndromes. Over the past decade, several research groups have contributed to the knowledge about the natural history of CMV infections in transplant patients. This information is an essential prelude to the design and conduct of controlled trials designed to interfere with natural history. Given this framework, the objectives of the laboratory are to guide clinical colleagues on potential management changes for individual patients under their care (Table 1). Each of these laboratory objectives will be considered in turn.

Pretransplant assessment: CMV antibodies of immunoglobulin (Ig) G class should be sought using one of a range of sensitive methods which are widely available. The presence of IgG antibodies in donors indicate that they are at risk of transmitting virus to the recipient (1). The presence of antibody in a recipient indicates that the patient is at risk of reactivating virus after transplantation (2). In the case of herpes simplex, the height of the pretransplant IgG level is generally predictive of future reactivation (3), but this is not true for CMV (4).

Post-transplant assessment: Once the patient is receiving immunosuppressive drugs, ability to mount a humoral immune response should not be relied upon for diagnostic purposes. Several methods exist for the detection of CMV. Cell culture remains the gold standard against which all newer methods must be compared. Nearly a decade ago, monoclonal antibodies reactive with the major immediate-early proteins of CMV were used in culture conformation to significantly shorten the time required for detection of CMV. This approach is termed DEAFF (detection of early antigen fluorescent foci) or shell vial technique $(5,6)$. The sensitivity is lower than that of cell culture but can be significantly increased by centrifugation of clinical sample and cell culture before incubation. Monoclonal antibodies have also been used to detect CMV-specific antigens in leukocytes (polymorphonuclear and monocytes) from cytospin preparation of peripheral blood (7-9). Monoclonal antibodies used for this technique do not react with immediate-early antigens as originally thought, but recognize an early phosphoprotein of molecular weight ratio 65,000 ,
TABLE 1

\section{Cytomegalovirus laboratory objectives}

\begin{tabular}{|c|c|}
\hline \multirow[t]{2}{*}{ Pretransplant } & $\begin{array}{l}\text { Detect latent cytomegalovirus in } \\
\text { recipient and donor }\end{array}$ \\
\hline & Advise on prophylaxis \\
\hline \multirow[t]{5}{*}{ Post-transplant } & Monitor to detect active infection \\
\hline & Provide prognostic information \\
\hline & Advise on treatment strategies \\
\hline & Detect resistant strains \\
\hline & Advise on alternative treatments \\
\hline
\end{tabular}

termed the lower matrix protein (10). Finally, several methods for the detection of CMV by polymerase chain reaction (PCR) have been described (11-13).

The diagnosis of CMV infection after transplantation should ideally be made by collection of regular surveillance samples taken from time of transplant onwards. Most laboratories collect weekly urine, saliva and blood for this purpose and process them by one or more of the methods described above. Wherever possible, samples from a diseased organ such as liver biopsy or bronchoalveolar lavage should be collected to provide evidence of tissue infection. CMV disease should be classified according to a clinical scoring scheme (Table 2) pioneered by Plotkin et al $(14,15)$ to facilitate evaluation of the protective responses of CMV vaccines.

Table 3 shows the use of this approach for three distinct groups of transplant patients under the care of clinical colleagues at the Royal Free Hospital School of Medicine. Samples from all patients were processed by cell culture and DEAFF. CMV infection is very common in transplant patients, but CMV disease does not occur in the same proportion of subgroups of patients. For example, in renal allograft patients, disease is largely restricted to those experiencing primary infection or reinfection from the donor organ (16). In contrast, bone marrow transplant patients have the most severe disease if their own virus is reactivated after transplantation (2). In our series, but not in others, a reduced incidence of disease was found if the marrow donor was seropositive (17). This may be due to the use of $\mathrm{T}$ cell depletion, which may remove the cells harbouring CMV infection, as well as those mediating graft-versus-host disease after transplantation. Under these circumstances, residual immunity in the donor may be adoptively transferred into the recipient (18). Since the donor marrow has been depleted of mature T cells, this suggests that the protective mechanism is non- $T$ in origin, presumably B cell-mediated. The possibility of adoptive transfer of humoral immunity has been investigated by immunizing donors immediately before transplantation; the best results were obtained when the recipient as well as the donor were immunized (19).

The results from surveillance cultures can be analyzed in a different way to determine how much prognostic information they produce for the average patient. 


\section{TABLE 2}

\section{Scoring system for severity of cytomegalovirus disease}

\begin{tabular}{|c|c|}
\hline Clinical manifestations & Points \\
\hline \multicolumn{2}{|l|}{ Fever $\left(\geq 38.3^{\circ} \mathrm{C}\right)$} \\
\hline Mild (two to four days) & 1 \\
\hline Moderate (five to 20 days) & 1 \\
\hline Severe ( $\geq 21$ days) & 3 \\
\hline Leukopenia $\left(<4 \times 10^{9} / \mathrm{L}\right)$ & 1 \\
\hline Thrombocytopenia $\left(<100 \times 10^{9} / \mathrm{L}\right)$ & 1 \\
\hline \multicolumn{2}{|l|}{ Hepatitis } \\
\hline Liver enzymes $\geq 2$ times normal & 1 \\
\hline Jaundice & 3 \\
\hline \multicolumn{2}{|l|}{ Pneumonia associated with cytomegalovirus } \\
\hline Infiltrate on x-ray & 1 \\
\hline Infiltrate and symptoms & 2 \\
\hline Ventilator support & 3 \\
\hline $\begin{array}{l}\text { Gastrointestinal bleeding or ulceration } \\
\text { (biopsy proven) }\end{array}$ & 3 \\
\hline \multicolumn{2}{|l|}{ Central nervous system changes } \\
\hline Lethargy & 1 \\
\hline Stupor & 2 \\
\hline Coma & 3 \\
\hline \multicolumn{2}{|l|}{ Renal insufficiency } \\
\hline $\begin{array}{l}\text { Creatinine level two to four times above } \\
\text { best pretransplant level }\end{array}$ & 1 \\
\hline $\begin{array}{l}\text { Creatinine level more than four times } \\
\text { above best pretransplant level }\end{array}$ & 2 \\
\hline Nephrectomy, permanent dialysis & 3 \\
\hline Arthritis or muscle wasting & 2 \\
\hline \multicolumn{2}{|l|}{ Superinfection } \\
\hline Bacterial, protozoal, fungal & 3 \\
\hline Death & 4 \\
\hline
\end{tabular}

Adapted from Plotkin (14,15)

Under these circumstances, the detection of CMV is assumed to be clinically useful only if it occurs in samples taken before the onset of disease in the patient. This approach was pioneered by the Seattle group, which showed an overall sensitivity of $69 \%$, with a positive predictive value for CMV viremia of $60 \%$ using blood cultures maintained for five weeks (20). In an attempt to make prognostic information more readily available to physicians, we have used the DEAFF test, and found a lower sensitivity of about $50 \%$ but a positive predictive value of $64 \%$ (21). In renal transplant patients, we found a sensitivity of $79 \%$ and a positive predictive value of viremia of $46 \%$ (22), with a similar trend for liver transplant patients (23). Clearly, these results indicate that the sensitivity of surveillance cultures needs to be improved, but that viremia provides good prognostic value when it is detected. These results should therefore support the more widespread introduction of pre-emptive therapy where asymptomatic patients with CMV viremia are treated with an antiviral drug such as ganciclovir (24). In addition, the study should prompt more widespread evaluation of 'suppression', defined as administration of an antiviral drug
TABLE 3

CMV infection and disease at The Royal Free Hospital

\begin{tabular}{lccccc}
\hline $\begin{array}{l}\text { Type of } \\
\text { transplant }\end{array}$ & $\begin{array}{c}\text { Pretransplant } \\
\text { IgG }\end{array}$ & R & $\begin{array}{c}\text { Number } \\
\text { of } \\
\text { patients }\end{array}$ & \multicolumn{2}{c}{ Number with CMV } \\
Infection & Disease \\
\hline Renal & - & - & 21 & 0 & 0 \\
& - & + & 34 & $21(62 \%)^{*}$ & $15(44 \%)^{*}$ \\
& + & - & 51 & $19(37 \%)^{*}$ & $3(6 \%)$ \\
Bone & + & + & 71 & $49(69 \%)^{*}$ & $18(25 \%)^{*}$ \\
marrow & - & - & 63 & $4(6 \%)$ & $2(3 \%)$ \\
& + & + & 23 & $6(26 \%)^{*}$ & $1(4 \%)$ \\
& + & - & 25 & $12(48 \%)^{*}$ & $11(44 \%)^{*}$ \\
Liver & + & + & 66 & $33(50 \%)^{*}$ & $8(12 \%)$ \\
& - & - & 4 & $1(25 \%)$ & $1(25 \%)$ \\
& + & + & 3 & $1(33 \%)$ & $1(33 \%)$ \\
& + & - & 18 & $2(11 \%)$ & $2(11 \%)$ \\
& + & + & 19 & $11(58 \%)^{*}$ & $6(32 \%)$ \\
\hline
\end{tabular}

"Significant difference from D-R-group; CMV Cytomegalovirus; D Donor: Ig Immunoglobulin: R Recipient

to patients excreting only from peripheral sites of urine and/or saliva (25). Finally, these results should also stimulate the conduct of formal prognostic studies for newer methods such as polymerase chain reaction (PCR), which offer greatly increased sensitivity. Such studies must be conducted at each laboratory as variations in cell culture lines, techniques used, lengths of incubation, and anticoagulants used, can significantly alter the performance of a particular assay and the cell culture result with which it must be compared. Viremia should, therefore, not be seen as an all or none phenomenon but as a continuum which will be detected more readily by the most sensitive assays, but which will not necessarily be associated with severe disease in all cases. The ability to quantify PCR reactions should facilitate a greater refinement of the prognostic value of these assays (26).

Detection of resistant strains: Soon after ganciclovir became widely available for the treatment of CMV infections, strains of virus with reduced in vitro sensitivity to the drug were reported. For example, Erice et al (27) showed that strains of virus could acquire resistance to ganciclovir or could be selected during the course of an infection in vivo. The precise pathological potential of such resistant strains must be determined, but it seems likely that alternative therapy will be required for at least some patients, as has been described for herpes simplex (28).

One resistant strain has been studied in detail using marker rescue techniques, and resistance has been shown to map to two distinct genes: DNA polymerase and the product of the UL97 gene $(29,30)$. By analogy with herpes simplex, the DNA polymerase mutant presumably has a reduced ability to recognize ganciclovir triphosphate. However, the UL97 gene provides a novel molecular target for CMV chemotherapy. The gene has been shown to code for a protein with a relative molecular mass of approximately 80,000, which is homologous 
to protein kinases. A truncated protein with a relative molecular mass of approximately 39,000 was expressed in Escherichia coli and contained all of the predicted catalytic domains of the protein kinases. Extracts from the $E$ coli were shown to phosphorylate ganciclovir and an antiserum reactive against UL97 was shown to neutralize the kinase activity.

An alternative drug for treating resistant strains is foscarnet. CMV strains resistant to ganciclovir are reported to be sensitive to this drug. In addition, the two drugs exhibit synergistic activity in vitro. They have been given together in patients, but there is at least one report of a strain of CMV resistant to both agents (31).

\section{HUMAN HERPESVIRUSES 6 AND 7}

Human herpesviruses 6 (HHV-6) and 7 (HHV-7) were not identified until 1986 and 1990, respectively, so much less information is available about their natural history than is the case for the other herpesviruses $(32,33)$. Nevertheless, it appears that infection with both is commonly acquired in early childhood and that both viruses are frequently excreted in saliva (34-37). This is supported by the results of in situ hybridization and immunocytochemistry of salivary glands (38). One report describes the isolation of $\mathrm{HHV}-7$ only from the saliva of adults, although this virus activated HHV-6 from the donor lymphocytes used for culture which became dominant subsequently (39). Most infected individuals exhibit no symptoms, suggesting that the natural history of these viruses resembles that of CMV or Epstein-Barr virus (EBV) rather than varicella-zoster virus (VZV). Molecular analyses of the genome of HHV-6 suggest that it is genetically related to CMV, with conserved blocks of genes colinear with their CMV counterparts (40). A map of restriction enzyme sites has been published (41).

HHV-6 has been shown to be the cause of exanthema subitum, a mild, self-limiting common childhood illness (42). Exanthema subitum was shown in 1950 to be transmissible to a six-month-old child and to macaques (43). In addition, case reports have associated HHV-6 with a variety of conditions. These are ranked in Table 4 , from those which are probably caused by the virus to those which are purely speculative. This speculation includes the suggestion that HHV-6 could act as a cofactor to increase the rate at which acquired immunodeficiency syndrome (AIDS) develops following infection with human immunodeficiency virus (HIV). This is based upon in vitro experiments which show that HHV-6 can increase HIV replication in co-infected cells by stimulating transcriptional factors (44), or by transactivation $(45,46)$, although this activation is dependent upon the reporter gene used (47). HHV-6 can up-regulate the CD4 molecule in CD8 cells to render them susceptible to HIV infection (48). However, another report shows that HHV-6 inhibits HIV replication in cell culture (49), while one serological clinical study does not support the hypothesis
TABLE 4

Conditions associated with human herpesvirus 6 infection

\begin{tabular}{lc}
\hline & References \\
\hline $\begin{array}{l}\text { Exanthema subitum, including complications: } \\
\text { mononucleosis }\end{array}$ \\
leukopenia/thrombocytopenia \\
hepatosplenomegaly & 72 \\
meningitis & 73 \\
encephalopathy & \\
fever & \\
Likely associations & \\
Meningitis & \\
Lymphadenopathy & \\
Mononucleosis & 74 \\
Hepatitis & 75,76 \\
Pneumonitis & 77 \\
Suppression of marrow function & \\
Speculative associations & $78-80$ \\
Post-viral fatigue syndrome & This study \\
Cofactor for human immunodeficiency virus & 57 \\
Lymphomas & 81 \\
Guillain-Barré syndrome & 82,83 \\
Collagen diseases & 84 \\
Intussusception & \\
\hline & \\
\hline
\end{tabular}

that HHV-6 adversely affects progression of HIV infection (50), although another does (51).

At present, there are no diseases associated with HHV-7 infection. Seroconversion to HHV-7 in a small number of healthy children appears to occur from the second year of life onwards (39).

Diagnosis of infection: Virus isolation has so far been the mainstay of diagnosis of this new herpesvirus $(52,53)$. Immediate-early antigens have been identified and could be used for rapid viral diagnosis (54). Several PCR methods have been described $(36,55-57)$. It is hoped that they, in conjunction with virus isolation, will be evaluated critically, as was described earlier for CMV, to help determine the true clinical significance of this virus (58).

In addition, some authors have begun to type strains of virus using slot-blot, restriction enzyme analysis, or PCR with sequencing of amplimers (59). Whether the strains associated with exanthema subitum should be differentiated taxonomically from the remaining strains is controversial (60).

The first serological tests used immunofluorescence, either using antihuman conjugates or using anticomplement immunofluorescence $(61,62)$. Given the genetic relationship with $\mathrm{CMV}$, the fact that the virus may activate host cell proteins (63) and the possibility that it may encode an $\mathrm{Fc}$ receptor, it has been difficult for investigators to determine uniequivocally a true cut-off between seropositive and seronegative. When serum dilutions of 1:80 are used in indirect immunofluorescence, then, typically, $80 \%$ of the population are shown 
to be seropositive. Serological responses in patients have been reported during CMV infections, and vice versa. Whether this results from antigenic cross-reaction or co-reactivation of both herpesviruses in immunocompromized patients, is unknown (64-66). Other serological methods have been described, including enzyme immunoassay $(67,68)$, IgM determination $(69,70)$, Western blotting (51) and radioimmunoprecipitation (71), but their specificity and sensitivity remain to be determined.

\section{REFERENCES}

1. Wertheim P, Buurman C, Geelen J, van-der-Noordaa J. Transmission of cytomegalovirus by renal allograft demonstrated by restriction enzyme analysis. Lancet 1983;i:980-1. (Lett)

2. Winston DJ, Huang ES, Miller MJ, et al. Molecular epidemiology of cytomegalovirus infections associated with bone marrow transplantation. Ann Intern Med 1985; 102:16-20.

3. Berry NJ, Grundy JE, Griffiths PD. Radioimmunoassay for the detection of IgG antibodies to herpes simplex virus and its use as a prognostic indicator of HSV excretion in transplant recipients. J Med Virol 1987;21:147-54.

4. Pillay D, Webster A, Lee D, Prentice HG, Griffiths PD. Cytomegalovirus excretion after bone marrow transplantation cannot be predicted from the pre-transplant level of IgG antibodies. J Med Virol 1991:33:257-9.

5. Griffiths PD, Panjwani DD, Stirk PR, et al. Rapid diagnosis of cytomegalovirus infection in immunocompromised patients by detection of early antigen fluorescent foci. Lancet 1984;ii:1242-5.

6. Gleaves CA, Smith TF, Shuster EA, Pearson GR. Rapid detection of cytomegalovirus in MRC-5 cells inoculated with urine specimens by using low-speed centrifugation and monoclonal antibody to an early antigen. J Clin Microbiol 1984;19:917-9.

7. van den Berg AP, Klompmaker IJ, Haagsma EB, et al. Antigenemia in the diagnosis and monitoring of active cytomegalovirus infection after liver transplantation. $\mathrm{J}$ Infect Dis 1991;164:265-70.

8. Revello MG, Percivalle E, Zavattoni M, Parea M, Grossi P, Gerna G. Detection of human cytomegalovirus immediate early antigen in leukocytes as a marker of viremia in immunocompromised patients. J Med Virol 1989;29:88-93.

9. van-der-Bij W, Schirm J, Torensma R, van-Son WJ, Tegzess AM, The TH. Comparison between viremia and antigenemia for detection of cytomegalovirus in blood. $\mathrm{J}$ Clin Microbiol 1988;26:2531-5.

10. Grefte JMM, van der Gun BTF, Schmolke S, et al. The lower matrix protein pp65 is the principal viral antigen present in peripheral blood leukocytes during an active cytomegalovirus infection. J Gen Virol 1992;73:2923-32.

11. Demmler GJ, Buffone GJ, Schimbor CM, May RA. Detection of cytomegalovirus in urine from newborns by using polymerase chain reaction DNA amplification. J Infect Dis 1988;158:1177-84.

12. Olive DM, al Mufti S, Simsek M, Fayez H, al Nakib W. Direct detection of human cytomegalovirus in urine specimens from renal transplant patients following polymerase chain reaction amplification. J Med Virol 1989:29:232-7.

13. Darlington J, Super M, Patel K, Grundy JE, Griffiths PD, Emery VC. Use of the polymerase chain reaction to

\section{CONCLUSION}

Work towards the laboratory diagnosis of HHV-6 is recapitulating that done decades earlier for CMV. It is hoped that progress will be more rapid, however, since we now have the benefit of using molecular biological approaches. When using these techniques, investigators should not ignore the complex natural history of herpesviruses and so will use the methods to differentiate clearly between clinical associations which are causal and those which are merely casual.

analyse sequence variation within a major neutralizing epitope of glycoprotein B (gp58) in clinical isolates of human cytomegalovirus. J Gen Virol 1991;72:1985-9.

14. Plotkin SA, Smiley ML, Friedman HM, et al. Townevaccine-induced prevention of cytomegalovirus disease after renal transplants. Lancet 1984;i:528-30.

15. Plotkin SA, Starr SE, Friedman HM, et al. Effect of Towne live virus vaccine on cytomegalovirus disease after renal transplant. A controlled trial. Ann Intern Med 1991; 114:525-31.

16. Grundy JE, Lui SF, Super M, et al. Symptomatic cytomegalovirus infection in seropositive kidney recipients: Reinfection with donor virus rather than reactivation of recipient virus. Lancet 1988;ii:132-5.

17. Grob JP, Grundy JE, Prentice HG, et al. Immune donors can protect marrow-transplant recipients from severe cytomegalovirus infections. Lancet 1987;i:774-6.

18. Wimperis JZ, Brenner MK, Prentice HG, et al. Transfer of a functioning humoral immune system in transplantation of T-lymphocyte-depleted bone marrow. Lancet 1986;: :339-43.

19. Wimperis JZ, Gottlieb D, Duncombe AS, Heslop HE, Prentice HG, Brenner MK. Requirements for the adoptive transfer of antibody responses to a priming antigen in man. J Immunol 1990;144:541-7.

20. Meyers JD, Ljungman P, Fisher LD. Cytomegalovirus excretion as a predictor of cytomegalovirus disease after marrow transplantation: Importance of cytomegalovirus viremia. J Infect Dis 1990;162:373-80.

21. Webster A, Blizzard B, Pillay D, Prentice HG, Pothecary K, Griffiths PD. The value of routine surveillance cultures for detection of CMV pneumonitis following bone marrow transplantation. Bone Marrow Transplant. (In press)

22. Pillay D, Ali A, Lui SF, Sweny P, Griffiths PD. The prognostic significance of positive CMV cultures during surveillance of renal transplant recipients.

Transplantation. (In press)

23. Pillay D, Charman H, Burroughs AK, Smith M, Rolles K, Griffiths PD. Surveillance for CMV infection in orthotopic liver transplant recipients. Transplantation 1992;53:1261-5

24. Schmidt GM, Horak DA, Niland JC, Duncan SR, Forman SJ, Zaia JA. A randomized, controlled trial of prophylactic ganciclovir for cytomegalovirus pulmonary infection in recipients of allogeneic bone marrow transplants; The City of Hope-Stanford-Syntex CMV Study Group. N Engl J Med 1991;324:1005-11.

25. Goodrich JM, Mori M, Gleaves CA, et al. Early treatment with ganciclovir to prevent cytomegalovirus disease after allogeneic bone marrow transplantation. N Engl J Med 1991;325: 1601-7.

26. Fox JC, Griffiths PD, Emery VC. Quantification of human cytomegalovirus DNA using the polymerase chain reaction. J Gen Virol 1992;73:2405-8.

27. Erice A, Chou S, Biron KK, Stanat SC, Balfour HHJ, Jordan MC. Progressive disease due to 
ganciclovir-resistant cytomegalovirus in immunocompromised patients. N Engl J Med 1989;320:289-93.

28. Safrin S, Crumpacker C, Chatis P, et al. A controlled trial comparing foscarnet with vidarabine for acyclovirresistant mucocutaneous herpes simplex in the acquired immunodeficiency syndrome. The AIDS Clinical Trials Group. N Engl J Med 1991;325:551-5.

29. Littler E, Stuart AD, Chee MS. Human cytomegalovirus UL97 open reading frame encodes a protein that phosphorylates the antiviral nucleoside analogue ganciclovir. Nature 1992:358:160-2.

30. Sullivan V, Talarico CL, Stanat SC, Davis M, Coen DM, Biron KK. A protein kinase homologue controls phosphorylation of ganciclovir in human cytomegalovirus-infected cells. Nature 1992;358:162-4.

31. Knox KK, Drobyski WR, Carrigan DR. Cytomegalovirus isolate resistant to ganciclovir and foscarnet from a marrow transplant patient. Lancet 1991;337:1292-3. (Lett)

32. Salahuddin SZ, Ablashi DV, Markham PD, et al. Isolation of a new virus, HBLV, in patients with lymphoproliferative disorders. Science 1986;234:596-601.

33. Frenkel N, Schirmer EC, Wyatt LS, et al. Isolation of a new herpesvirus from human CD4+ T cells. Proc Natl Acad Sci USA 1990;87:748-52.

34. Briggs M, Fox J, Tedder RS. Age prevalence of antibody to human herpesvirus 6. Lancet 1988;i:1058-9. (Lett)

35. Levy JA, Ferro F, Greenspan D, Lennette ET. Frequent isolation of HHV-6 from saliva and high seroprevalence of the virus in the population. Lancet 1990;335:1047-50.

36. Gopal MR, Thomson BJ, Fox J, Tedder RS, Honess RW Detection by PCR of HHV-6 and EBV DNA in blood and oropharynx of healthy adults and HIV-seropositives. Lancet 1990;335:1598-9. (Lett)

37. Jarrett RF, Clark DA, Josephs SF, Onions DE. Detection of human herpesvirus-6 DNA in peripheral blood and saliva. J Med Virol 1990;32:73-6.

38. Fox JD, Briggs M, Ward PA, Tedder RS. Human herpesvirus 6 in salivary glands. Lancet 1990;336:590-3.

39. Wyatt LS, Frenkel N. Human herpesvirus 7 is a constitutive inhabitant of adult human saliva. J Virol 1992;66:3206-9.

40. Thompson BJ, Martin MED, Nicholas J. The molecular and cellular biology of human herpesvirus-6. Rev Med Virol 1991;1:89-99.

41. Martin ME, Thomson BJ, Honess RW, et al. The genome of human herpesvirus 6: Maps of unit-length and concatemeric genomes for nine restriction endonucleases. J Gen Virol 1991;72:157-68.

42. Yamanishi K, Okuno T, Shiraki K, et al. Identification of human herpesvirus-6 as a causal agent for exanthem subitum. Lancet 1988;i:1065-7.

43. Kempe CH, Shaw EB, Jackson JR, Silver HK. Studies on the etiology of exanthema subitum (roseola infantum). J Pediatr 1950;37:561-8.

44. Ensoli B. Lusso P. Schachter F, et al. Human herpes virus-6 increases HIV- 1 expression in co-infected T cells via nuclear factors binding to the HIV-1 enhancer. EMBO J 1989;8:3019-27.

45. Geng YQ, Chandran B, Josephs SF, Wood C. Identification and characterization of a human herpesvirus 6 gene segment that transactivates the human immunodeficiency virus type 1 promoter. J Virol 1992;66: 1564-70.

46. Horvat RT, Wood C, Josephs SF, Balachandran N. Transactivation of the human immunodeficiency virus promoter by human herpesvirus 6 (HHV-6) strains GS and Z-29 in primary human T lymphocytes and identification of transactivating HHV-6(GS) gene fragments. J Virol 1991;65:2895-902.

47. Campbell ME, McCorkindale S, Everett RD, Onions DE. Activation of gene expression by human herpesvirus 6 is reporter gene-dependent. J Gen Virol 1991;72:1123-30.

48. Lusso P, De Maria A, Malnati M, et al. Induction of CD4 and susceptibility to HIV-1 infection in human CD8+ T lymphocytes by human herpesvirus 6 . Nature 1991;349:533-5.

49. Levy JA, Landay A, Lennette ET. Human herpesvirus 6 inhibits human immunodeficiency virus type 1 replication in cell culture. J Clin Microbiol 1990;28:2362-4.

50. Spira TJ, Bozeman LH, Sanderlin KC, et al. Lack of correlation between human herpesvirus- 6 infection and the course of human immunodeficiency virus infection. $\mathrm{J}$ Infect Dis 1990;161:567-70.

51. Chen H, Pesce AM, Carbonari M, et al. Absence of antibodies to human herpesvirus- 6 in patients with slowly-progressive human immunodeficiency virus type 1 infection. Eur J Epidemiol 1992:8:217-21.

52. Luka J, Okano M. Thiele G. Isolation of human herpesvirus-6 from clinical specimens using human fibroblast cultures. J Clin Lab Anal 1990;4:483-6.

53. Harnett GB, Farr TJ, Pietroboni GR, Bucens MR. Frequent shedding of human herpesvirus 6 in saliva. J Med Virol 1990;30:128-30.

54. Eizuru Y, Minamishima Y. Evidence for putative immediate early antigens in human herpesvirus 6-infected cells. J Gen Virol 1992;73:2161-5.

55. Collandre H, Aubin JT, Agut H, Bechet JM, Montagnier L. Detection of HHV- 6 by the polymerase chain reaction. J Virol Methods 1991;31:171-9.

56. Kido S, Kondo K, Kondo T, Morishima T, Takahashi M, Yamanishi K. Detection of human herpesvirus 6 DNA in throat swabs by polymerase chain reaction. J Med Virol 1990;32:139-42.

57. Saito I, Nishimura S, Kudo I, Fox RI, Moro I. Detection of Epstein-Barr virus and human herpes virus type 6 in saliva from patients with lymphoproliferative diseases by the polymerase chain reaction. Arch Oral Biol 1991;36:779-84.

58. Asano Y, Nakashima T, Yoshikawa T, Suga S, Yazaki T. Severity of human herpesvirus- 6 viremia and clinical findings in infants with exanthem subitum. J Pediatr $1991 ; 118: 891-5$.

59. Aubin JT, Collandre H, Candotti D, et al. Several groups among human herpesvirus 6 strains can be distinguished by Southern blotting and polymerase chain reaction. J Clin Microbiol 1991;29:367-72.

60. Schirmer EC, Wyatt LS, Yamanishi K, Rodriguez WJ, Frenkel N. Differentiation between two distinct classes of viruses now classified as human herpesvirus 6. Proc Natl Acad Sci USA 1991:88:5922-6.

61. Robert C, Agut H, Aubin JT, et al. Detection of antibodies to human herpesvirus-6 using immunofluorescence assay. Res Virol 1990;141:545-55.

62. Couillard M, Joly JR, Deschenes L, Richer G. Evaluation of variables in immunofluorescence procedures for the detection of antibodies against human herpesvirus 6 (HHV-6). Diagn Microbiol Infect Dis 1992;15:313-20.

63. Black JB, Lopez C, Pellett PE. Induction of host cell protein synthesis by human herpesvirus 6 . Virus Res 1992;22:13-23.

64. Irving WL, Ratnamohan VM, Hueston LC, Chapman JR, Cunningham AL. Dual antibody rises to cytomegalovirus and human herpesvirus type 6: Frequency of occurrence in $\mathrm{CMV}$ infections and evidence for genuine reactivity to 
both viruses. J Infect Dis 1990;161:910-6.

65. Ward KN, Sheldon MJ, Gray JJ. Primary and recurrent cytomegalovirus infections have different effects on human herpesvirus- 6 antibodies in immunosuppressed organ graft recipients: Absence of virus cross-reactivity and evidence for virus interaction. J Med Virol 1991;34:258-67.

66. Sutherland S, Christofinis G, O'Grady J, Williams R. A serological investigation of human herpesvirus 6 infections in liver transplant recipients and the detection of cross-reacting antibodies to cytomegalovirus. J Med Virol 1991;33:172-6.

67. Asano Y, Yoshikawa T, Suga S, et al. Enzyme-linked immunosorbent assay for detection of IgG antibody to human herpesvirus 6. J Med Virol 1990;32:119-23.

68. Dahl H, Linde A, Sundqvist VA, Wahren B. An enzyme-linked immunosorbent assay for IgG antibodies to human herpes virus 6. J Virol Methods 1990;29:313-23.

69. Farr TJ, Harnett GB, Pietroboni GR, Bucens MR. The distribution of antibodies to HHV-6 compared with other herpesviruses in young children. Epidemiol Infect 1990;105:603-7.

70. Fox JD, Ward P, Briggs M, Irving W, Stammers TG, Tedder RS. Production of IgM antibody to HHV-6 in reactivation and primary infection. Epidemiol Infect 1990; 104:289-96.

71. Yoshiyama H, Suzuki E, Yoshida T, Kajii T, Yamamoto N. Role of human herpesvirus 6 infection in infants with exanthema subitum. Pediatr Infect Dis J 1990;9:71-4.

72. Irving WL, Chang J, Raymond DR, Dunstan R, Grattan Smith P, Cunningham AL. Roseola infantum and other syndromes associated with acute HHV-6 infection. Arch Dis Child 1990;65:1297-300.

73. Ishiguro N, Yamada S, Takahashi T, et al. Meningoencephalitis associated with HHV-6 related exanthem subitum. Acta Paediatr Scand 1990;79:987-9.

74. Sobue R, Miyazaki H, Okamoto M, et al. Fulminant hepatitis in primary human herpesvirus-6 infection. N Engl J Med 1991;324:1290. (Lett)

75. Carrigan DR, Drobyski WR, Russler SK, Tapper MA, Knox
KK, Ash RC. Interstitial pneumonitis associated with human herpesvirus-6 infection after marrow transplantation. Lancet 1991;338:147-9.

76. Russler SK, Tapper MA, Knox KK, Liepins A, Carrigan DR. Pneumonitis associated with coinfection by human herpesvirus 6 and Legionella in an immunocompetent adult. Am J Pathol 1991; 138:1405-11.

77. Knox KK, Carrigan DR. In vitro suppression of bone marrow progenitor cell differentiation by human herpesvirus 6 infection. J Infect Dis 1992;165:925-9.

78. Daugherty SA, Henry BE, Peterson DL, Swarts RL, Bastien S, Thomas RS. Chronic fatigue syndrome in northern Nevada. Rev Infect Dis 1991;13 (Suppl 1):S39-44.

79. Buchwald D, Freedman AS, Ablashi DV, et al. A chronic 'postinfectious' fatigue syndrome associated with benign lymphoproliferation, B-cell proliferation, and active replication of human herpesvirus-6. J Clin Immunol 1990;10:335-44.

80. Steeper TA, Horwitz CA, Ablashi DV, et al. The spectrum of clinical and laboratory findings resulting from human herpesvirus-6 (HHV-6) in patients with mononucleosis-like illnesses not resulting from Epstein-Barr virus or cytomegalovirus. Am J Clin Pathol 1990;93:776-83.

81. Merelli E, Sola P, Faglioni P, Poggi M, Montorsi M, Torelli G. Newest human herpesvirus (HHV-6) in the GuillainBarre syndrome and other neurological diseases. Acta Neurol Scand 1992;85:334-6.

82. Baboonian C, Venables PJ, Maini RN, Kangro HO, Osman HK. Antibodies to human herpesvirus-6 in Sjogren's syndrome. Arthritis Rheum 1990;33:1749-50. (Lett)

83. Hoffmann A, Kirn E, Kuerten A, Sander C, Krueger GR, Ablashi DV. Active human herpesvirus-6 (HHV-6) infection associated with Kikuchi-Fujimoto disease and systemic lupus erythematosus (SLE). In Vivo 1991;5:265-9.

84. Asano Y, Yoshikawa T, Suga S, Hata T, Yamazaki T, Yazaki T. Simultaneous occurrence of human herpesvirus 6 infection and intussusception in three infants. Pediatr Infect Dis J 1991:10:335-7. 


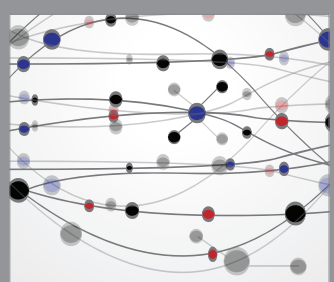

The Scientific World Journal
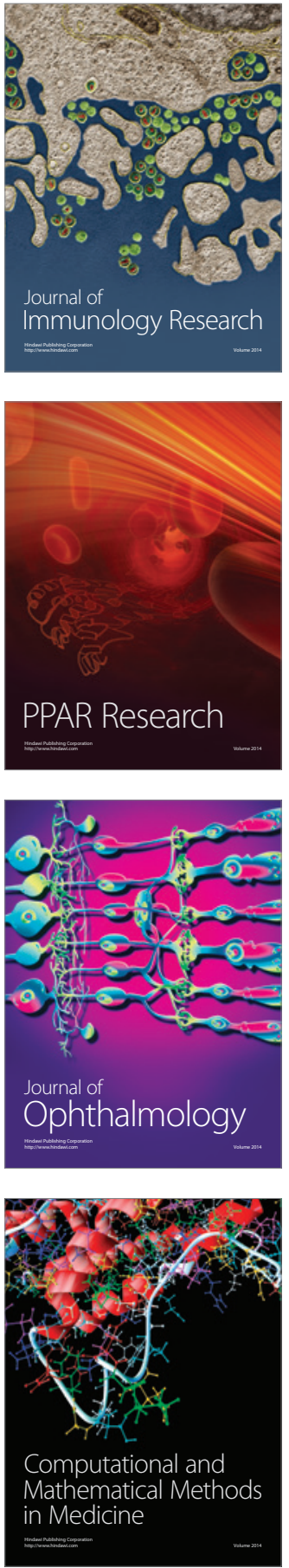

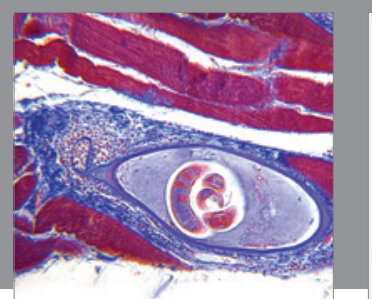

Gastroenterology Research and Practice

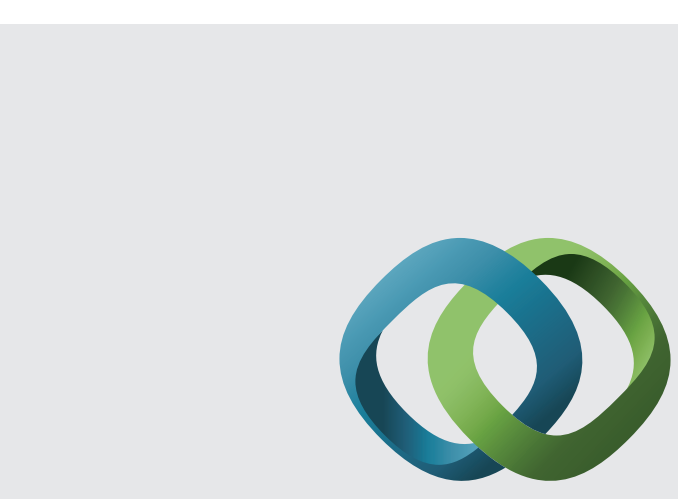

\section{Hindawi}

Submit your manuscripts at

http://www.hindawi.com
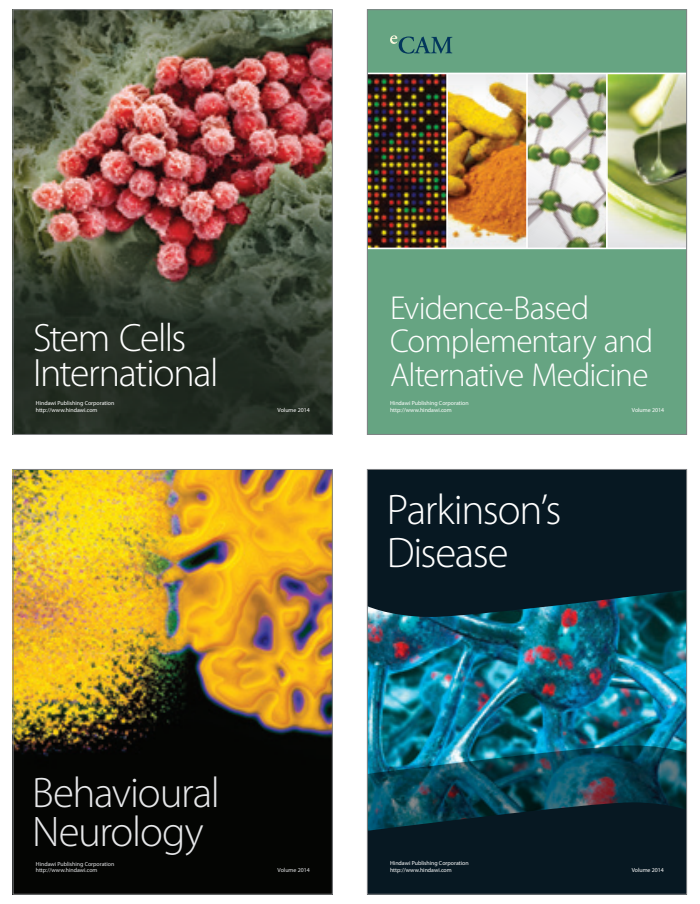
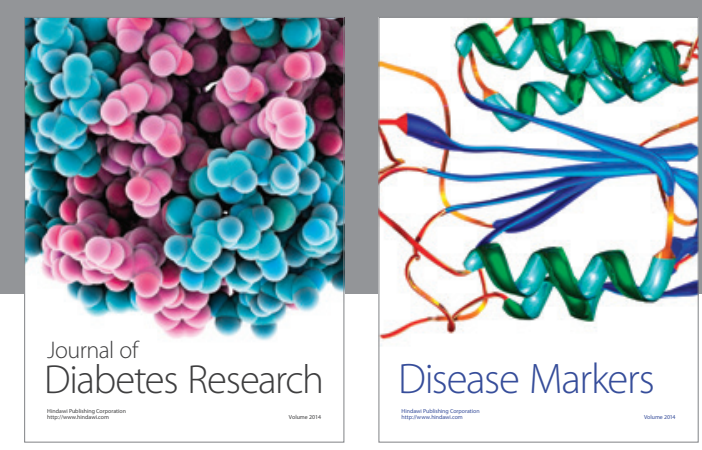

Disease Markers
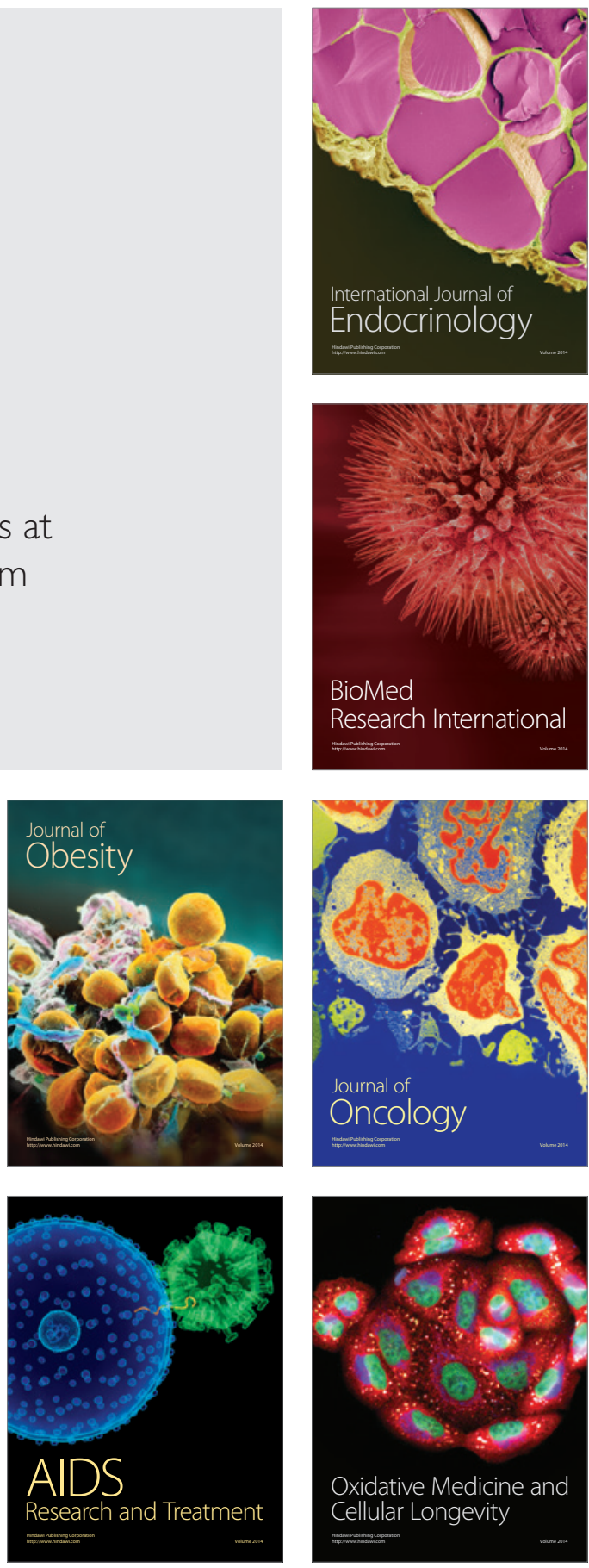